\title{
Transplacental haemorrhage in women having third trimester bleeding and perinatal outcome
}

\author{
Shakuntala Chhabra*, Preetindar Kaur, Chandan Tickoo, Prashant Zode \\ Obstetrics \& Gynaecology, Mahatma Gandhi Institute of Medical Sciences, Sevagram, Wardha, Maharashtra, India. \\ E-mail: ${ }^{*}$ chhabra_s@rediffmail.com
}

Received 12 April 2011; revised 10 June 2011; accepted 20 June 2011.

\begin{abstract}
Objectives: Present prospective study was carried out to know the frequency of transplacental fetomaternal hemorrhage in pregnancies complicated by third trimester vaginal bleeding and it's correlation with fetoneonatal outcome. Material methods: One hundred, out of $170 \mathrm{Rh}$-positive primigravida/multigravida with singleton pregnancy of more than 28 weeks gestation, admitted with third trimester vaginal bleeding with no other obstetric disorder, were the study subjects and 100 controls were women with no bleeding, admitted immediately after the study case with same inclusion and exclusion criteria. Maternal peripheral blood was collected at admission and at 2 hours of delivery and volume of FMH was calculated by Kleihauer's formula. Results: Statistically significantly more perinatal deaths occurred in women with FMH, 35\% in study subjects compared to $2.7 \%$ amongst controls. Conclusion: In the cases of third trimester bleeding and fetomaternal hemorrhage, chances of perinatal deaths are more.
\end{abstract}

Keywords: Third Trimester Bleeding; Foetomaternal Haemorrhage; Perinatal Death; Fetal Haemoglobin; Perinatal Outcome

\section{INTRODUCTION}

Fetomaternal hemorrhage (FMH) is known to occur in upto $70 \%$ of pregnancies but the amount of bleeding is less than $0.1 \mathrm{ml}$ in the majority [1-3], however on rare occasions, it may be massive and fatal [4,5]. Massive FMH may occur in 1:1000 deliveries. It is more common after traumatic diagnostic amniocentesis or external cephalic version, also after placental abruption and trauma. However in most of the cases, the cause is unexplained [6,7]. Pregnancies complicated by antepartum hemorrhage (APH), like placental abruption $(\mathrm{P} \mathrm{Ab})$, Placenta Previa (PP) and Unclassified Hemorrhage
(UCH) have been considered high risk for FMH $[8,9]$. Gordon and Bhoyroo [10] were the first to report massive FMH in APH and now some researchers recommend looking for FMH in every case of APH [2,3,11,12].

A number of methods have been used to determine the amount of FMH. The acid elution test described by Kleihauer Braun and Betke [13] has been the landmark, the simplest for the detection of fetal cells. This test is based on resistance by hemoglobin $\mathrm{F}$ from the cell to elution in an acid medium. Many other tests, including alkaline denaturation tests described by Apt and Downey [14] known as APT Test and Ogita Test [15] have been tried since then. The newer sophisticated and expensive methods limit their use in low resource settings.

\section{OBJECTIVES}

The present prospective study was carried out to know the frequency of Transplacental FMH (TPFMH) in pregnancies complicated by third trimester vaginal bleeding and to study it's correlation with the fetoneonatal outcome.

\section{MATERIAL AND METHODS}

During the study period of 26 months, 170 cases of third trimester vaginal bleeding were admitted. Inclusion criteria for the study were Rh-positive primigravida/multigravida with singleton pregnancy of more than 28 weeks gestation with vaginal bleeding and no other obstetric disorder. Controls were pregnant women with singleton pregnancy of more than 28 weeks gestation who got admitted immediately after the study case with same inclusion and exclusion criteria except no bleeding, (not even concealed bleeding), so these cases were of pain in abdomen/labour pains without any disorder.

Hundred women out of 170 cases of APH admitted during study period and 100 controls without APH selected randomly, (depending on the availability of the investigator for collection of blood at the time of admission of study subject) were subjected to investigations for FMH. 
After informed consent Kleihauer-Betke [16] test was performed on maternal peripheral blood at admission and within 2 hours of delivery in the study subjects and controls. Volume of FMH was calculated by using Kleihauer's formula [17].

\section{RESULTS}

Of the 100 study subjects, 23 were of PP, $42 \mathrm{P} \mathrm{Ab}$ and 35 UCH. Overall 40 out of 100 study cases and 24 controls had FMH at the time of admission [statistically significantly more study cases ( $\mathrm{p}$ value $<0.05$ ) compared to controls], also significantly more cases of $\mathrm{P}$ Ab [23 (54.7\%)] compared to PP [8 (34.7\%)], UCH [9 (25.7\%)] and controls (24\%) (P value < 0.05) had FMH.

Fifty six study cases and 37 controls had FMH post delivery, statistically significant difference (p value < 0.05 ). Post delivery, there was increase in cases with FMH in study, from $40 \%$ to $56 \%$ and in controls from $24 \%$ to $37 \%$, FMH was statistically significantly more post delivery compared to pre-delivery both in study and control cases ( $\mathrm{p}$ value $<0.05$ ). Of 23 cases of PP 15 (65.2\%), of $42 \mathrm{P} \mathrm{Ab} 24$ (57.1\%) and of 35 cases of UCH 17 (48.5\%) had FMH post delivery. FMH increased statistically significantly more post delivery in cases of PP (65.2\% VS $34.7 \%$, p value < 0.05$)$ and in UCH $(48.5 \%$ vs $25.7 \%$, p value $<0.05)$. There was no significant increase in cases with FMH post delivery in $\mathrm{P} \mathrm{Ab}(57.1 \%$ and $54.7 \%$, p value $>0.05$ ).

Of the 40 study subjects with FMH, 20 (50\%) had less than $0.25 \mathrm{ml}, 11$ (27.5\%) had FMH between $0.25 \mathrm{ml}-1$ $\mathrm{ml}$ and 9 (22.5\%) had more than $1 \mathrm{ml} \mathrm{FMH}$. Of the 24 con- trols with FMH, 21 (87.5\%) had less than $0.25 \mathrm{ml}$ FMH and 3 (12.5\%) had between 0.25 to $1 \mathrm{ml}$ and none more than $1 \mathrm{ml}$ FMH (Pie Diagram 1).

Of the $40(40 \%)$ study subjects with FMH at admission, 26 (65\%) had live births, 14 (35\%) stillbirths, two (5\%) neonatal deaths occurred, however all 24 controls with FMH had live births. And of 60 study cases without FMH, 49 (81.7\%) had live births, 11 (18.3\%) stillbirths occurred significantly more (p value $<0.05$ ) and amongst 76 controls with no FMH, 74 (97.6\%) had live births, 2 (2.6\%) stillbirths occurred.

Overall of the 100 study subjects, 56 (56\%) had FMH post delivery, 42 (75\%) of them had live births and 14 (25\%) stillbirths and 37 controls had FMH post delivery, all had live births. Of the 44 study subjects with no FMH post delivery, 34 (77.3\%) had live births, 10 (22.7\%) stillbirths occurred and of 63 controls with no FMH post delivery 61 (96.7\%) had live births and 2 (3.3\%) stillbirths occurred (Bar Diagram 1).

Of study subjects with FMH at admission, 40\% perinatal deaths (PD), occurred compared to $4.1 \%$ in controls (statistically significant difference p value $<0.05$ ),
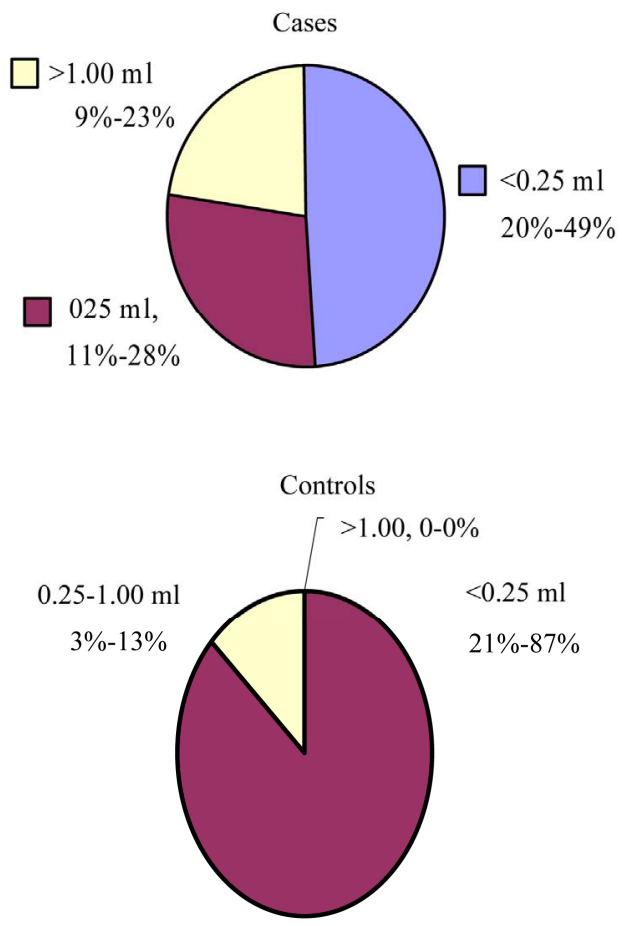

Pie Diagram 1. FMH at admission.

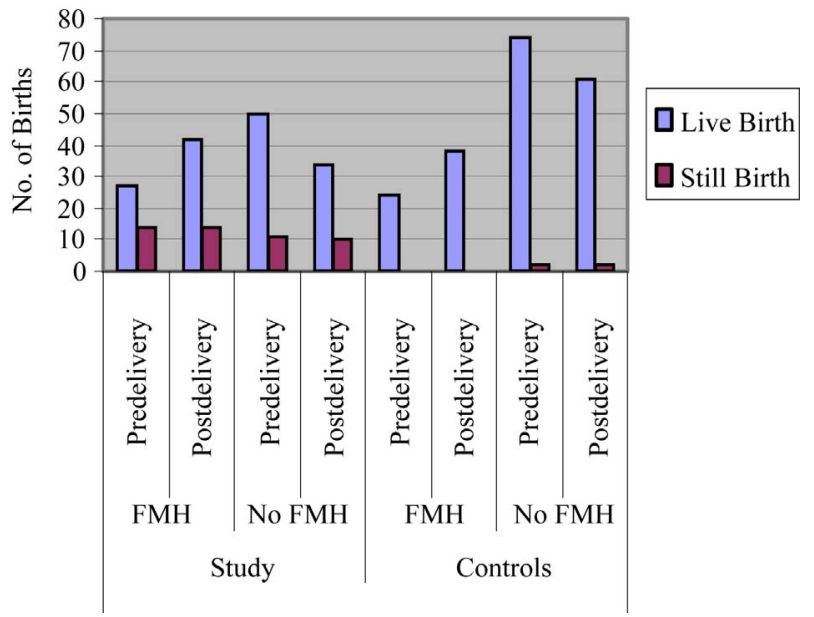

Bar Diagram 1. Live birth and still birth.

25\% in PP with FMH,43.4\% in P Ab and 44.4\% in $\mathrm{UCH}$, statistically significantly more in $\mathrm{P} \mathrm{Ab}$ and $\mathrm{UCH}$ than $\mathrm{PP}$ (p value $<0.05$ ). With no FMH at admission, 26.6\% study cases and 5.2\% controls had PD, [statistically significant difference ( $\mathrm{p}$ value $<0.05$ )], however PD were $52.5 \%$ in cases of $\mathrm{P} \mathrm{Ab}, 13.2 \%$ cases of $\mathrm{PP}$ and $15.3 \%$ UCH had statistically significantly more in $\mathrm{P} \mathrm{Ab}$ (p value $<0.05$ ).

In study subjects with $\mathrm{FMH}<0.25 \mathrm{ml}$ at admission, $20 \%$ PD occurred and with $>1 \mathrm{ml} \mathrm{FMH} 77.7 \%$ had PD ( $p$ value $<0.05$, statistically significant difference).

In study cases with post delivery FMH, 35.7\% had PD 
compared to $2.7 \%$ in controls, statistically significant difference ( $\mathrm{p}$ value $<0.05$ ). With post delivery FMH, PD occurred in $20 \%$ cases of PP, $54.1 \%$ of P Ab and $23.5 \%$ of UCH cases \{statistically significant difference ( $\mathrm{p}$ value $<0.05$ ) between $\mathrm{P} \mathrm{Ab}$, PP and $\mathrm{UCH}\}$. Of the total study subjects with no FMH, post delivery, $27.2 \%$ and in controls $6.3 \%$ had PD [statistically significant difference (p value $<0.05$ )]. With no FMH at admission in 38.8\% cases of P Ab, PD occurred compared to $12.5 \%$ cases of $\mathrm{PP}$ and $22.2 \%$ cases of $\mathrm{UCH}$, statistically significant difference ( $\mathrm{p}$ value $<0.05$ ) between $\mathrm{P} \mathrm{Ab}$ and other two conditions.

\section{DISCUSSION}

FMH has been reported to occur in $25 \%-50 \%$ of all pregnancies $[18,19]$ however higher incidence $(60 \%$ $70 \%$ ) has been reported in pregnancies complicated by bleeding in third trimester [1,4,12,20-22].

Theoretically placental separation may lead to increased chances of fetal blood going into maternal circulation. But there have been conflicting reports about the presence of FMH in cases of third trimester bleeding. The clinical manifestations and prognosis with FMH depend on the hemorrhage and the rapidity with which hemorrhage occurs. If the hemorrhage is small, prolonged or repeated the fetus gets an opportunity to develop hemodynamic compensation with increased hemopoietic activity (increased reticulocytes and erythroblasts in the peripheral smear). The diagnosis is often postnatal and these infants may manifest only pallor at birth. However rapid blood loss could lead to intrauterine hypoxia and death or severe anemia and hypoxia at birth. A decrease in the fetal movements associated with abnormal cardiotocographic findings, such as a sinusoidal pattern of the fetal heart rate, may be a warning sign of a massive FMH, especially in a low risk pregnancy [7].

Management of massive hemorrhage requires immediate delivery by caeserian section, if the gestational age is suitable, alternatively for very premature fetuses serial fetal intravascular transfusions could be used if facilities and experienced personnel are available.

In the present prospective pilot study, one hundred women with third trimester bleeding and one hundred controls were investigated for FMH. At admission, FMH was found in $40 \%$ study subjects and $24 \%$ controls, significantly more in P Ab (54.7\%) compared to PP (34\%), UCH (25.7\%) and controls (24\%). No evidence of increase in FMH in third trimester vaginal bleeding, has been reported by Frazer and Raper [23], Zipursky [24], Sebring and Polesky [11],high between 20\% and 43.4\% by Kizza and Rogo [25], Stettler [26] and Boyle [12], much higher (75.8\%) reported by Minchin and Bhoyroo [27] and a low incidence of $8.1 \%$ has also been reported by Holcomb [28], who carried out KB test in 205 women who had various problems including vaginal bleeding in 49 (33\%).

Substantial increase in frequency of passage of fetal erythrocytes immediately after delivery has been reported [19]. In the present study, post delivery FMH was $56 \%$ in the study subjects and $37 \%$ in controls, increase in FMH in study subjects from 40 to $56 \%$ and from 24 to $37 \%$ in controls did not affect the neonatal outcome. Choavartana [4] has reported FMH in 76\% post delivery cases similar to the present study. In cases of separation of placenta, chances of hemorrhage seem to be more during the time of delivery.

Of study cases with FMH at admission, statistically significantly more PD occurred compared to controls. Further, PD in P Ab and UCH cases with FMH at admission as well as post delivery were statistically significantly more than PP ( $\mathrm{p}$ value $<0.05$ ). Amongst study subjects with post delivery FMH, 35\% PD occurred compared to $2.7 \%$ amongst controls. Higher PD in pregnancies complicated by FMH in third trimester bleeding has been reported by other researchers $[5,11,29,30]$ also.

\section{CONCLUSIONS}

Present study revealed that there are more chances as well as there is more volume of FMH in cases of APH, more so in $\mathrm{P} A \mathrm{Ab}$, some others also report the same [5,21,22]. In study cases with FMH $<0.25 \mathrm{ml}$ at admission, 20\% had PD and with FMH $>1 \mathrm{ml}, 77.7 \%$ had PD (p value $<0.05$ ). Present study has limitations but does reveal the necessity of more studies to have the appropriate strategies of management of cases of APH to ensure an optimal perinatal outcome.

\section{REFERENCES}

[1] Marions, L. and Thomassen, P. (1991) Six cases of massive fetomaternal bleeding causing intra-uterine fetal death. Acta Obstetical et Gynecologica Scandinavica, 70, 85-88. doi:10.3109/00016349109006184

[2] Arias, F. (2000) Third trimester bleeding. In: Practical guide to high risk pregnancy and delivery. 2nd Edition, Singapore, Harcourt Brace Asia, 162-182.

[3] Claydon, C.S. and Pernoll, M.L. (2003) Third trimester vaginal bleeding. In: de cheeney ah, nathan l, eds. current obstetric and gynecologic diagnosis and treatment 9th ed. Lange Medical Books and Mc Graw Hill Company, New York, 354-368.

[4] Choavartana, R., Ver-Arrewong, S. and Makanantakosal, S. (1997) Fetomaternal transfusion in normal pregnancy and during delivery. Journal of the Medical Association of Thailand, 80, 96-100.

[5] Cunningham, F.G., Gant, N.F., Leveno, K.J., Gilstrap, L.C., Hauth, J.C. and Wenstrom, K.O. (2001) Obstetric hemorrhage. Williams obstetrics. 21st Editon, Interna- 
tional edition, Mc Graw Hill, 619-635.

[6] Almeida, V., Bowman, J.M., Victor, M.D. and John, M.D. (1994) Massive fetomaternal hemorrhage, manitoba experience. Obstetrics and Gynecology, 83, 323328.

[7] Giacoia, G.P. (1997) Severe FMH: A review. Obstetric Gynecology Survey, 52, 372-380. doi:10.1097/00006254-199706000-00022

[8] O’Connolly, A.M., Katz, V.L., Bash, K.L., McMahon, M.J. and Hansen, W.F. (1997) Trauma \& pregnancy. American Journal of Perinatology, 14, 331.

[9] Jansen, M.W., Korver-Hakkennes, K., Van Leenen, D, Visser, W., Groot, C.J. and Wladimiroff, J.W. (2001) Significantly higher number of fetal cells in the maternal circulation of women with preeclampsia. Prenat Diagn, 21, 1022-1026. doi:10.1002/pd.176

[10] Gordon, H. and Bhoyroo, S.K. (1966) A study of fetal erythrocytes in the maternal circulation during the antenatal period. Obstetrics and Gynecology, 73, 571574. doi:10.1111/j.1471-0528.1966.tb15535.x

[11] Sebring, S.H. and Polesky, H.F. (1990) Fetomaternal hemorrhage incidence, risk factor, time of occurrence, and clinical effects. Transfusion, 30, 344-357. doi:10.1046/j.1537-2995.1990.30490273444.x

[12] Boyle, J., Kin, J., Walerius, H. and Sammuels, B. (1996) The clinical use of the Kleihauer Betke test in Rh positive patients. American Journal of Obstetrics and Gynecology, 174, 343.

[13] Kleinhuer, E., Braun, H. and Betke, K. (1957) Demonstration von fetalen hemoglobin in den erythrocytes eins Blutanuss-trichs. Klin Wochenschr, 35, 637. doi:10.1007/BF01481043

[14] Apt, L. and Downey, W.S., (1955) Melena Neonatorum, the swallowed blood syndrome, a simple test for the differentiation of adult \& fetal hemoglobin in bloody stools. The Journal of Pediatrics, 47, 6-12. doi:10.1016/S0022-3476(55)80118-7

[15] Ogita, S., Ishiko, O., Matsumoto M, Hasegawa H. and Sugawa, T. (1976) A simplified method of measuring fetal hemoglobin. Obstetrics and Gynecology, 48, 237238.

[16] Kleinhauer, E. and Betke, K. (1960) Practical use of the demonstrated of cells containing hemoglobin $\mathrm{F}$ in fixed blood smears. Internist (Berlin), 1, 292-295.

[17] Kleinhuer, E., (1966) Fetalen hemoglobin and fetale erythrocytes. Suppl Arch Kinderheilk, 53, 76.
[18] Bartsch, F.K. (1972) Fetale eruthrozten immutterlichen Blut and immunoprophylaxe der Rh immunisierung. Acta Obstet Gynecol Scand ( Suppl), 20, 1-128.

[19] Jorgensen, J. (1977) Fetomaternal bleeding, bleeding. Acta Obstet Gynaecol Scand, 56, 7-490

[20] Burch, D. (1997) Computerised measurement of fetal heart rate variation in a case of FMH. British Journal Obstetrics \& Gynecology, 101, 1089.

[21] Froen, J.F., Vege, A. and Ormerod, E. (2001) StrayPedersen B. Finding the cause of death in intrauterine death-which examination should be done? PMID 11242876. Tidsskr nor Laegeforen, 121, 326-30.

[22] Jones, D.R. and Smith, T.R. (2004) Transplacental hemorrhage in pregnancies complicated by third trimester bleeding. Acta Obstet Gynecol Scand, 50, 65-67.

[23] Frazer, I.D. and Raper, A.B. (1962) Observation of compatible and incompatible and fetal red cells in the maternal circulation. Provincial Medical and Surgical Journal British Medical Journal, 2, 303-304.

[24] Zipursky, A. (1971) The universal prevention of $\mathrm{Rh}$ immunization. Clin Obstet Gynecol, 14, 869-884. doi:10.1097/00003081-197109000-00013

[25] Kizza, A.P. and Rogo, K.O. (1990) FMH in Kenya. East African Medical Journal, 67, 801-807.

[26] Stettler, R.W. and Lutich, A., Pritchard, T.A. and Cunningham, F.G. (1992) Traumatic placental abruption. Presented at the American College of Obstet Gynecol. Annual clinical meeting, Las Vagas, April 1992.

[27] Minchin, A.J. and Bhoyroo, S.K. (1970) Feto-maternal transfusion in APH, an index of placental damage \& fetal risk. Obstetrics and Gynecology, 77, 781-784. doi:10.1111/j.1471-0528.1970.tb04398.x

[28] Halcomb, W.L. Gunderson, E. and Petrie, R.H. (1990) Clinical use of the kleihauer betke test. Journal of Perinatal Medicine, 18, 331-337. doi:10.1515/jpme.1990.18.5.331

[29] Samadi, R., Greenspoon, J.S., Gviazda, I., Settlage, R.H. and Goodwin, T.M. (1999) Massive fetomaternal hemorrhage and fetal death are they predictable. Journal of Perinatology, 19, 227-229. doi:10.1038/sj.jp.7200144

[30] Zizka, Z., Calda, P., Zlatohlavkova, B., Haakova, L., Cerna, M., Jirasek, J.E., Fait, T. and Hajtk, Z. (2001) Kvasnicka JMassive peritology problem, role of ABO fetomaternaal compatibility-case studies. Mdical Science Monitor, 7, 308-311. 